\title{
POTRET PEMIKIRAN RADIKAL JARINGAN ISLAM LIBERAL (JIL) INDONESIA
}

\author{
Muh. Idris \\ STAIN Manado \\ idrispasca_uin@yahoo.co.id
}

\begin{abstract}
Abstrak
Jaringan Islam Liberal adalah salah satu lokomotifyang menggerakan tata nilai pemikiran keagamaan yang menekankan pada pemahaman Islam yang terbuka, toleran, inklusif dan kontekstual. Di Indonesia penyebaran Islam liberal telah berlangsung sejak awal tahun 70-an dan sejak tahun 2001, sejumlah aktivis dan intelektual muda Islam memulai penyebaran gagasan Islam liberal secara lebih terorganisir. Jaringan Islam Liberal mencoba membangun dan mengembangkan suasana beragama yang transformatif dan inklusif, menampakkan signifikansinya untuk selalu "dilirik" oleh komunitas umat. Melalui pemahaman keagamaan yang holistik dan pola keagamaan yang inklusif, umat Islam diharapkan dapat menyelesaikan krisis kemanusiaan, serta menjadikan modernitas sebagai proses yang memberikan manfaat sebesar-besarnya bagi manusia.
\end{abstract}

Abstract

THE PORTRAIT OF THE LIBERAL ISLAMIC NETWORK (JIL)'S RADICAL THOUGHTS OF OF INDONESIA. The Liberal Islam Network (JIL) is one of the intelectual communites generating the values of religious thoughts that emphasize on the open, tolerant, inclusive and contextual understandings of Islam. The spread of liberal Islam has been going on In Indonesia since the early 1970s as a number of activists and Muslim intellectuals began to deploy more organized liberal Islamic ideas. The Liberal Islam Network has been trying to build and to develop such a transformative, inclusive, religious atmosphere and showing its significance to attract Muslim community. Through a holistic, inclusive religious understanding, Muslims are expected to resolve humanitarian crises, and view modernity as a process that provides maximum benefits to the life of all humankind.

Kata Kunci : Radikal; Jaringan Islam Liberal dan Liberal 


\section{A. Pendahuluan}

Sejak terjadinya peristiwa kelabu yang menimpa World Trade Center (WTC) dan Pantagon di Amerika Serikat 11 September 2001 yang lalu, istilah terorisme menjadi global issue. Terorisme merupakan bagian dari radikalisme yang pada hakekatnya ada dimana-mana dan di semua bentuk dan jenis agama manapun di dunia ini. Kesan kuat terhadap pemikiran radikalisme dikaitkan erat dengan Islam muncul dalam wacana dunia sejak peristiwa WTC itu dengan menjadikan al-Qaeda sebagai prime suspect-nya.

Di samping gerakan radikal yang diketagorikan sebagai terorisme itu, di Indonesia muncul gerakan-gerakan radikal baik dalam hal pemikiran maupun disertai gerakan. Gerakan radikal yang hanya bersifat pemikiran belaka seperti Hizbut Tahrir Indonesia yang menghendaki ditegakkannya sistim khilafah dalam sistem politik dan pemerintahan. Sedangkan gerakan radikal yang hanya bersifat gerakan tetapi tidak menghendaki perubahan terdapat dalam pemikiran seperti Front Pembela Islam (FPI). Disamping itu ada juga yang merupakan kombinasi dari keduanya seperti yang ditampilkan Laskar Jihad (LJ) di Maluku atau lainnya.

Pada dasarnya radikalisme diartikan sebagai sesuatu yang "tidak biasa". HTI, FPI, LJ merupakan organisasi yang menampilkan kesan "tidak biasa". Gagasan dan aksi mereka yang "tidak biasa" itu telah menimbulkan reaksi darisebagian masyarakat muslim.Jaringan Islam Liberal (JIL) merupakan salah satu yang bereaksi terhadap organisasi-organisasi di atas. Menariknya dalam beraksi tersebut JIL juga menunjukkan pemikiran yang “tidak biasa”. Dalam membahas tema tersebut, tulisan ini diawali dengan memperkenalkan awal mula munculnya JIL, kemudian dilanjutkan dengan pembahasan mengenai aktivitas JIL, serta corak pemikiran radikal dari Jaringan Islam Liberal Indonesia.

\section{B. Mengenal Jaringan Islam Liberal}

Pertengahan tahun 2001, nama Islam Liberal mulai dikenal luas di Indonesia. Segera nama itu menjadi perbincangan di tengah masyarakat. Dengan semboyan "Islam yang membebaskan" kelompok yang kemudian mengusung bendera "Jaringan Islam 
Liberal disingkat JIL berhasil membetot perhatian banyak kalangan baik yang pro maupun yang kontra. ${ }^{1}$

Istilah liberal mengacu kepada keadaan atau sikap orang atau sebuah gerakan pemikiran tertentu yang bersedia merekonstruksi dan menghargai gagasan atau perasaan orang lain, yang juga mendukung perubahan-perubahan baik sosial, ekonomi, politik dan keagamaan melalui "pembebasan" pemikiran dari pandangan dunia dan sikap literal-dogmatis, reaksioner atau pro status quo. ${ }^{2}$ Dalam konteks ini, berarti Islam tidak saja dikembangkan dalam area pemikiran murni dan spekulatif tetapi harus juga diletakkan pada posisi netral.

Jaringan Islam Liberal adalah salah satu lokomotif yang menggerakkan tata nilai pemikiran keagamaan yang menekankan pada pemahaman Islam yang terbuka, toleran, inklusif dan kontekstual. Di Indonesia penyebaran Islam liberal telah berlangsung sejak awal tahun 70-an. Yang termasuk tokoh pemikir liberal pada situs islamlib.com, antara lain adalah Nurcholish Madjid, Masdar F. Mas'udi, Goenawan Muhammad, Djohan Efendi, Jalaluddin Rahmat, Nazaruddin Umar, Komaruddin Hidayat, dan Ulil Abshar Abdalla. ${ }^{3}$ Meskipun belum dikenal sebagai Islam liberal, pemikiran-pemikiran liberal seperti Cak Nur yang sering disebut sebagai pemikiran neo modernisme Islam, menjadi dasar dari pengembangan Islam liberal dewasa ini. Sejak tahun 2001, sejumlah aktivis dan intelektual muda Islam memulai penyebaran gagasan Islam liberal secara lebih terorganisir. Mereka ini kemudian mendirikan Jaringan Islam Liberal (JIL).

Kitab suci agama Islam pada dasarnya merupakan prinsip dan petunjuk yang bersifat keagamaan dan moral, bukan sebuah "dokumen" hukum. ${ }^{4}$ Dalam posisi seperti ini kehidupan Sunnah berada meskipun tidak dalam kedudukan yang sama. Kedua sumber

${ }^{1}$ Adian Husaini dan Nuim Hidayat, Sejarah, Konsepsi, Penyimpangan dan Jawabannya, (Jakarta: Gema Insani, 2012), h. vii.

${ }^{2}$ Azyumardi Azra, Konflik Baru Antara Peradaban, Globalisasi, Radikalisme dan Pluralitas, (Jakarta: Rajawali Press, 2002), h. 112.

${ }^{3}$ Bahtiar Effendy, Teologi Baru Politik Islam, Pertautan Agama, Negara dan Demokrasi, (Yogyakarta: Galang Press, 2001), h. 69.

${ }^{4}$ Fazlur Rahman, Islam, (Chicago dan London: Unv. Of Chicago Press, 1973), h. 73 . 
ajaran Islam tersebut merupakan Islam normatif yang bernilai absolut dan universal. Tugas umat Islam adalah untuk memahami nilai-nilai dan pesan yang dikandungnya secara holistik, terpadu, sistematis, dan selalu dikontekstualisasikan ke dalam kehidupan yang nyata sehingga selalu aktual, berpihak pada pengembangan keadilan, kedamaian, kesejahteraan dan semacamanya.

JIL selalu membuka diri pada pengembangan wawasan keislaman yang lebih dinamis sebagai berikut: ${ }^{5}$

\section{Keterbukaan pintu ijtihad pada semua aspek.}

Islam liberal percaya bahwa ijtihad atau penalaran rasional atau teks-teks keislaman adalah prinsip utama yang memungkinkan Islam terus bisa bertahan dalam segala suasana dan keadaan. Penutupan pintu ijtihad secara terbatas atau secara keseluruhan adalah ancaman atas Islam itu sendiri, sebab dengan demikian Islam akan mengalami pembusukan. Islam liberal percaya bahwa ijtihad dapat diselenggarakan dalam hampir semua segi Ilahiyat (teologi), Ubudiyat (ritual) atau Muamalat (interaksi sosial). Ruang ijtihad dalam bidang ubudiyat memang lebih sempit jika dibandingkan dengan ijtihad di dua bidang yang lain.

2. Penekanan pada semangat religio etik, bukan pada makna literal sebuah teks.

Ijtihad yang dikembangkan oleh Islam liberal adalah upaya menafsirkan Islam berdasarkan semangat religi etik al-Qur'an dan sunnah nabi, bukan menafsirkan Islam semata-mata berdasarkan makna literal sebuah teks. Penafsiran yang literal hanya akan membunuh perkembangan Islam. Hanya dengan penafsiran yang mendasarkan diri pada semangat religio etik, Islam akan dapat hidup dan berkembang secara kreatif menjadi bagian dari peradaban kemanusiaan yang universal.

\section{Kebenaran yang relatif terbuka dan plural.}

Islam liberal mendasarkan diri pada gagasan tentang kebenaran sebagai sesuatu yang relatif, sebab sebuah penafsiran adalah kegiatan manusiawi yang terkungkung oleh konteks tertentu,

${ }^{5}$ Yusuf Qardawi, Islam dan Globalisasi Dunia, terj, (Jakarta: Pustaka alKautsar, 2001), h.74. Lihat pula, Budi Winarno, Globalisasi Wujud Imperialisme Baru, (Yogyakarta: Tajidu Press, 2004), h.83. 
terbuka, sebab setiap bentuk penafsiran mengandung kemungkinan salah, selain kemungkinan benar "plural," sebab sebuah penafsiran keagamaan dalam satu akan lain cara adalah cerminan dari kebutuhan seorang penafsir disuatu masa dan ruang yang terus berubah-ubah.

\section{Pemihakan pada minoritas dan tertindas.}

Islam liberal mendasarkan diri pada suatu penafsiran keislaman yang memihak kepada yang kecil tertindas dan dipinggirkan. Setiap struktur sosial politik yang melaksanakan praktek ketidakadilan terhadap minoritas adalah berlawanan dengan semangat Islam. Minoritas yang dipahami dalam makna yang luas, mencakup minoritas agama, etnik, ras, budaya, politik, ekonomi, orientasi seksual dan lain-lain. Dalam konteks tersebut, di atas JIL mencoba memperluas wawasan berfikir yang lebih toleran dan saling menyapa diantara sesama ciptaan Tuhan dari beragam lapisan masyarakat, guna mewujudkan tatanan berfikir yang lebih sehat dan dinamis dalam membentuk budaya dan peradaban yang lebih anggun dan elok.

\section{Kebebasan beragama dan berkepercayaan.}

Islam liberal menganggap bahwa urusan beragama adalah hak perorangan yang harus dilindungi. Islam liberal tidak bisa membenarkan dasar suatu pendapat atau kepercayaan. Kepercayaan kepada agama dalam perspektif ini adalah sesuatu yang pokok, jelas dan universal yang mampu membentuk karakter pribadi yang lebih elegan dan mampu mengimplementasikan mana ajaran yang bersifat dasar dan mana yang non dasar, dengan suasana demikian akan membentuk nilai-nilai budaya berfikir yang lebih inovatif dan kreatif yang berujung terciptanya suasana masyarakat yang lebih humanis dan harmonis.

\section{Pemisahan otoritas duniawi dan ukhrawi, otoritas agama dan politik.}

Islam liberal percaya pada keniscayaan pemisahan antara kekuasaan keagamaan dan politik. Islam liberal tidak membenarkan gagasan tentang negara agama dimana otoritas seseorang ulama atau kyai dipandang sebagai kekuasaan tertinggi yang tidak bisa salah. Bentuk negara yang sehat untuk pertumbuhan agama dan 
politik adalah suatu negara yang dua wewenang yang dipisahkan agama adalah sumber inspirasi yang dapat mempengaruhi kebijakan publik, tetapi agama tidak serta merta mempunyai "privelse transendental" yang tidak bisa disangkal untuk menentukan segala bentuk kebijakan publik. Pada akhirnya adalah bekerja pada ruang privat dan perorangan. Urusan publik haruslah diselenggarakan melalui proses "ijtihad kolektif", di mana pelbagai pihak boleh saling menyangkal kebenaran ditentukan secara induktif melalui uji pendapat. ${ }^{6}$

Islam liberal menggambarkan prinsip yang dianut yang menekankan kebebasan pribadi (sesuai dengan doktrin kaum Mu'tazilah tentang kebebasan manusia) dan pembebasan struktur sosial politik dari dominasi yang tidak sehat dan menindas. Arah Islam liberal mempunyai dua makna sekaligus; kebebasan (being liberal) dan pembebasan (liberating).

\section{Aktivitas Jaringan Islam Liberal}

JILdalam konteks keindonesiaan sangatkentalmengartikulasi dan menelaah nilai-nilai pemikiran Islam yang universal guna mengangkat harkat dan martabat manusia sebagai umat yang terbaik disisi Allah melalui pemikiran dan kreativitas. Ada empat kegiatan atau aktivitas pokok Islam liberal adalah sebagai berikut :

1. Sindikasi penulisan Islam liberal. Maksudnya adalah mengumpulkan tulisan sejumlah penulis yang selama ini dikenal (atau belum dikenal) oleh publik yang luas sebagai pembela pluralisme dan inklusivisme. Sindikasi ini akan menyediakan bahan-bahan tulisan, wawancara dan artikel yang baik untuk koran-koran di daerah yang biasanya mengalami kesulitan untuk mendapatkan penulis yang baik. Dengan adanya otonomi daerah maka peran media lokal semakin penting dan suara-suara keagamaan yang toleran juga penting untuk disebarkan melalui media daerah ini. Setiap minggu akan disediakan tiga artikel untuk koran-koran daerah.

2. Talk-show di Kantor Berita Radio 68 H. Talk show ini mengundang sejumlah tokoh yang selama ini dikenal sebagai pendekar

${ }^{6}$ Fauzan al-Anshori, Melawan Konspirasi Jaringan Islam Liberal, (Yogyakarta: Pustaka al-Furqan, 2003). 
pluralisme untuk berbicara berbagai isu sosial keagamaan di tanah air. Acara ini akan diselenggarakan setiap minggu dan disiarkan oleh seluruh jaringan KBR $68 \mathrm{H}$ di seluruh Indonesia. Talk show ini akan diikuti oleh 10 radio: 4 radio di Jabotabek yaitu radio At-Tahiriyah, Muara FM, Star FM, Ria FM dan 6 radio di daerah yaitu radio Smart (Manado), DMS (Maluku), UNISI (Yogyakarta), PTPN (Solo), Mara (Bandung) dan radio Prima FM yang merupakan jaringan $68 \mathrm{H}$. Jadi melalui jaringan informasi pemikiran liberal yang syarat dengan muatan ilmiah dan intelektual tersebar dengan sendirinya dapat massif. Dengan semangat tersebut masyarakat keagamaan dapat menyaring dan menjaring informasi untuk memaknai dan mengeksplorasikannya.

3. Penerbitan Booklet. JIL mencoba membuat booklet ukuran sederhana setebal 40-50 halaman, berisi utuh, wawancara atau ringkasan dari tulisan yang ada yang berisi isu-isu yang acapkali menjadi bahan perdebatan dalam agama dan sering kali menjadi alat kelompok-kelompok tertentu untuk melancarkan kampanye mereka, seperti jihad, penerapan syari'at Islam, penerapan ajaran memerintahkan yang baik, dan mencegah dari yang jahat, konsep tentang pembangunan rumah ibadah dan lain-lain. Booklet ini diterbitkan dua bulan sekali dan dicetak sebanyak 1000 buah. Booklet tersebut di atas dijadikan sebagai media ringan guna mengakses informasi dari perkembangan pemikiran Jaringan Islam Liberal.

4. Website islamlib.com. Program ini berawal dari dibukanya mailing list Islam Liberal (isalamliberal@yahoogroups.com) yang mendapat respon positif. Ada usulan dari beberapa anggota untuk meluaskan mailing list ini ke dalam bentuk website yang bisa diakses oleh semua kalangan. Sementara mailing list tetap dipertahankan untuk kalangan terbatas saja. Semua program kampanye, buletin, sindikasi media, talk show radio akan dimuat dalam website ini. Web ini juga akan memuat setiap perkembangan berita, artikel atau apapun yang berkaitan dengan misi jaringan Islam liberal. ${ }^{7}$

${ }^{7}$ Ibid. 


\section{Corak Pemikiran JIL di Indonesia}

Munculnya berbagai corak pemikiran Islam di Indonesia tidak bisa dipisahkan begitu saja dengan kebijakan politik pembangunan di bawah rezim Orde Baru yang dirasakan oleh intelektual Islam, sangat memojokkan dan memarjinalkan kelompok Islam. Umat Islam selalu toleran membangun Orde Baru diterapkan benar-benar mengalami proses peminggiran yang dahsyat dan bertabrakan dengan arah modernisasi, terutama yang hanya mengarah pada pertumbuhan sektor ekonomi, tidak diimbangi dengan sektor religius. ${ }^{8}$

Setelah merespon kebijakan pembangunan di bawah Orde Baru, pemikiran Islam terus berkembang ke arah yang lebih luas dan subtansial, sehingga muncul pelbagai corak pemikiran Islam yang sangat penting diperhatikan dalam perkembangan pemikiran keagamaan Islam di Indonesia. Suasana peta pemikiran Islam di Indonesia, dapat dikategorikan menjadi formalistik, substansialistik, transformalistik, totalistik, idealistik dan realistik . ${ }^{9}$

${ }^{8}$ Lihat Fachri Aly dan Bahtiar Effendy, Merambah Jalan Baru Islam, (Bandung: Mizan, 1987). Lihat Pula Bahtiar Effendy, yang memberi pengantar, pada Oliver Roy, Gagalnya Islam Politik, (Jakarta: Serambi Ilmu Semesta, 1996).

${ }^{9}$ Tipe pertama pemikiran formalistik dari kalangan cendikiawan Muslim merupakan tipologi pemikiran Islam yang mengutamakan dan meneguhkan ketaatan secara ketat pada format-format ajaran islam. Dalam konteks pemikiran politiknya, tipe pemikiran formalistik menunjukkan orientasi yang cenderung menopang bentuk-bentuk masyarakat politik Islam yang dibayangkan, seperti mewujudkan suatu "sistem politik Islam," munculnya partai Islam, ekspresi Islam simbolis dan idiom-idiom politik, kemasyarakatan, budaya Islam serta eksperimen ketatanegaraan.

Tipe kedua, pemikiran subtansialistik, pola pemikiran ini mengajukan argumen bahwa yang paling penting dari seseorang adalah aksentuasi substansi iman atau peribadatan, bukan hal-hal yang sifatnya simbolik formalistik dan ketaatan literal kepada teks wahyu Tuhan dalam keberagamaan.

Tipe ketiga, pemikiran transformatik, sebuah pandangan pemikiran yang bertolak bahwa Islam yang utama adalah kemanusiaan. Oleh sebab itu secara terus menerus umat Islam harus menjadi kekuatan yang dapat melakukan motivasi dan menstransformasi masyarakat dari pelbagai aspeknya dalam skala teoritis maupun praksis.

Tipe keempat, pemikiran totalistik, adalah sebua pola pemikiran yang mendasarkan bahwa Islam merupakan doktrin yang kaffah (total), mengandung wawasan dan nilai-nilai yang bersifat komplit dan langgeng yang meliputi seluruh 
A. Syafii Ma'arif membedakan corak pemikiran Islam menjadi empat, yakni modernis dan diteruskan oleh neo-modernis, neo-tradisionalis, ekslusif Islam, dan modernis sekularis muslim. ${ }^{10}$ Sementara M. Dawam Raharjo membedakan corak pemikiran Islam menjadi nasionalis muslim, humanis, sosialis-sekuler muslim, dan modernis-sekuler. ${ }^{11}$

Nurcholish Madjid dalam buku Islam Kemodernan dan Keindonesiaan mengapresiasi konsep modernisasi ialah identik dengan rasionalisasi. Konsep tersebut bermuara pada liberalisasi pemikiran yang berupaya merombak pola pikir dan tata kerja lama yang tidak akliyah, menggantinya dengan pola pikir dan tata kerja baru yang akliyah. ${ }^{12}$ Manfaatnya adalah untuk memperoleh daya guna dan efisiensi yang maksimal. Hal itu dilakukan demi menciptakan iklim pemahaman keberagamaan yang lebih pluralis, harmonis, dan dinamis, guna membangun budaya ilmu yang ilmiyah dan alamiah.

Berdasarkan penjelasan di atas, perkembangan pola dan corak pemikiran Islam ternyata tidak berhenti sampai di situ, tetapi terus berkembang sampai sekarang. Banyak hal yang direspon oleh para pemikir Islam di atas. Beberapa tema pokok yang direspon oleh para cendikiawan muslim antara lain, soal Islam dan negara nasional

aspek sosial, politik, ekonomi, segi-segi individu, kolektif maupun masyarakat, menurutnya tidak ada ruang kosong untuk menerima partikularistik dan kemajemukan dengan dasar Islam.

Tipe kelima, pemikiran idealistik, sebuah pemikiran Islam yang mengarah pada "Islam cita-cita" (ideal Islam) sebagai dasar perjuangannya.

Keenam, Pemikiran realistik. Pemikiran ini berusaha menempatkan antara Islam doktrin (ajaran Islam) sebagai ajaran subtansialis dengan realitas sosial kultural yang ada dan terus berkembang sesuai dengan kontek masyarakatnya. Lihat Zuli Qadir, Wajah Islam Liberal di Indonesia: Sebuah Penjajagan Awal, (Yogyakarta: Jurnal Al Jami’ah, Vol. 40, No. 2, Juli-Desember 2002) h. 335-337. Lihat pula, Yusuf Qardawi, Islam Radikal; Analisis Terhadap Radikalisme dalam Berislam dan Upaya Pemecahannya, (Terj.), (Solo: IKAPI, 1996), h.113.

${ }^{10}$ Ahmad Syafii Ma'arif, Peta Bumi Pemikiran Islam di Indonesia, (Bandung: Mizan, 1992), h.12-13.

${ }^{11}$ M.Dawam Raharjo, Intelektual, Intelegensia dan Prilaku Politik Bangsa, (Bandung: Mizan, 1992), h. 23-41.

${ }^{12}$ Nurcholish Madjid, Islam Kemodernan Dan Keindonesiaan, (Bandung: Mizan, 1989). h.172. 
Islam, Islam dan Keindonesiaan, Islam dan kemodernan, Islam dan demokrasi, Islam dan pluralisme. ${ }^{13}$

Tema-tema tersebut di atas menjadi fokus pembicaraan cendikiawan muslim karena tema-tema ketika berhadapan dengan rezim Orde Baru yang banyak melakukan penekanan dan intervensi dalam gerakan Islam di Indonesia, sehingga melahirkan gebrakan pemikiran yang liberal dan dinamis.

Komunitas Islam liberal sangat aktif dalam sosialisasi pemikiran-pemikiran Islam, yang merupakan kelanjutan dari sosialisasi pemikiran Islam era 90-an, mereka dilatar belakangi HMI, NU, Paramadina dan NGO lain, dan yang sebagian sedang atau telah menyelesaikan studinya (S.2/ S.3) di luar negeri, baik Eropa, Amerika maupun Timur Tengah. Nama-nama seperti Ulil Abshar Abdalla dari Lakpesdam NU dan ISAI Jakarta, Nurcholish Madjid dan Budi Munawar Rachman (Paramadina), Nazaruddin Umar (Rahima), Rizal Malarangeng (Freedom Instutute), Saiful Muzani (Ohio University), Ihzan Ali Fauzi (Jerman) dan lain-lain merupakan tokoh sentral kajian JIL (Jaringan Islam Liberal), ISAI (Institut Studi Arus Informasi) dan KUK (Kajian Utan Kayu).

Secara historis, pemikir-pemikir Islam liberal banyak yang mendukung demokrasi, menentang teokrasi, jaminan pada hakhak kaum perempuan, hak-hak non muslim di negara Islam, dan pembebasan terhadap kebebasan berfikir. ${ }^{14}$ Salah satu tema yang paling hangat dibahas oleh komunitas pemikir liberal Islam adalah perlunya pemisahan yang tegas antara agama dan politik, atau agama dan negara. Dalam pandangan liberal Islam, agama berbeda dengan politik. Agama berurusan langsung dengan Tuhan dan berimbas pada manusia, sedangkan politik adalah urusan antara manusia yang imbasnya juga antar-manusia. Tidak ada sakralitas dalam politik, yang ada hanya etika, sementara dalam agama ada

${ }^{13}$ Bahtiar Effendy, Islam dan Negara, (Jakarta: Paramadina, 1998). A. Syafi'i Ma'arif, Islam dan Masalah Kenegaraan, (Jakarta: LP3S, 1985). M. Rusly Karim, Cendikiawan Muslim Indonesia dan Politik Orde Baru, (Yogyakarta:Tiara Wacana, 1998). Maskuri Abdillah, Islam dan Politik Orde Baru, (Yogyakarta: Tiara Wacana, 1998).

${ }^{14}$ Charles Kurzman (Ed.), Wacana Islam Liberal, Pemikiran Islam Kontemporer Tentang Isu-Isu Global, (Jakarta: Paramadina, 2003), h. xiii-iii. Bandingkan Juga Leonard Binder, Islamic Liberalism A Critique of Depvelopment Ideologis, (Cicago \& London: Cicago Press,1988), h. 4. 
hal-hal yang sakral. Memang keduanya bisa bertemu dalam etika universal bukan doktrin.

Bahtiar Effendy dengan mengutip pendapat Nurcholish Madjid, menjelaskan kaitan antara Islam dan politik di Indonesia yaitu:

1. Keterkaitan antara yang setidak-tidaknya dianggap sakral (agama) dan yang profan (politik).

2. Dalam kritik sejarah, keterkaitan antara Islam dan politik ini menyangkut soal ijtihad dan keikhlasan para pemikir dan aktivitas Islam generasi pertama.

3. Akibat-akibat yang ditimbulkan oleh pemikiran dan aktivitas politik Islam di masa lampau. ${ }^{15}$

Demikian pula Soekarno (sebelum jadi Presiden) pernah menulis sebuah artikel berjudul "memudahkan Islam". menurut Soekarno langkah-langkah pemikiran liberalisasi yang dijalankan oleh Kemal Attaturk adalah "tindakan paling modern" dan tindakan "paling radikal". Katanya "Agama dijadikan urusan perorangan". Bukan Islam itu dihapuskan oleh Turki, tetapi Islam itu diserahkan kepada manusia-manusia Turki sendiri dan tidak kepada negara. Oleh karena itu, salahlah kalau kita mengatakan bahwa Turki adalah anti-agama, anti-Islam. Salahlah kita, kalau kita samakan Turki itu dengan, misalnya, Rusia”. ${ }^{16}$

Mengutip Frances Woodmall, Soekarno telah mencatat bahwa:

"Perilaku Turki modern terhadap Islam adalah sikap antiortodoksi, atau anti-institusi keagamaan, ketimbang disebut sebagai anti agama... Validitas Islam sebagai agama yang menjadi persoalan keyakinan pribadi tidak ditolak. Tidak ada penghentian pelaksanaan ritual agama di masjid, atau lebihlebih pelaksanaan kegiatan kegamaan"17

${ }^{15}$ Bahtiar Effendy, Masyarakat Agama dan Pluralisme Keagamaan,Perbincangan mengenai Islam, Masyarakat Madani dan Etos Kewirausahaan, (Yogyakarta: Galang Press, 2001), h. 69.

${ }^{16}$ M.Thalib dan Haris Fajar, Dialog Bung Karno - A. Hassan, (Yogyakarta: Sumber Ilmu, 1985), h. 75-89.

${ }^{17}$ Ibid. 
Menurut Soekarno apa yang dilakukan Turki sama sebagaimana dilakukan oleh negara-negara Barat, seperti Inggris, Perancis, Belanda, Belgia, Jerman dan lain-lainya, dimana urusan agama diserahkan kepada masing-masing pemeluknya, agama dijadikan urusan pribadi dan tidak dijadikan urusan negara, tidak dijadikan sebagai agama resmi negara.

Kemal Attaturk juga menghapus hukum-hukum Allah, dari masyarakat Turki. Tulisan Arab digantikan tulisan Latin, azan harus menggunakan bahasa Turki, dengan demikian pengaruh Islam kata Soekarno lebih didominasi oleh Negara/Pemerintah. Faktanya penguasa Islam pada waktu itu tidak menjalankan dan memelihara Islam sebagaimana yang diajarkan Islam. Bahkan tidak jarang agama hanya dijadikan alat untuk memepertahankan legitimasi kekuasaan.

Dalam wawancara dengan harian Kompas tanggal 1 April $1970,{ }^{18}$ Nurcholish mengatakan, "Orang yang menolak sekularisasi lebih baik mati saja. Karena sekularisasi adalah inheren dengan kehidupan manusia sekarang di dunia ini”. Ini diartikan juga bahwa zaman atau keadaan sekarang, juga berarti dunia ini. Pada makalah lain Nurcholis mengatakan, agama Islam, bila diteliti benar-benar dimulai dari proses sekularisasi terlebih dulu. Justru ajaran tauhid menurutnya, itu merupakan pangkal tolak proses sekularisasi terlebih dulu.

Di lain sisi, Nurcholish juga mengatakan, "Dari tinjauan yang lebih prinsipil, konsep 'Negara Islam' adalah suatu distorsi, hubungan proporsional antara agama dan negara. Negara adalah salah satu segi kehidupan duniawi yang dimensinya adalah rasional dan kolektif, sedangkan agama adalah aspek kehidupan yang dimensinya spiritual dan pribadi." Sosok ketokohan Nurcholish Madjid sebagai locomotif pembaharuan Islam yang liberal rasional dan fugsional.

Greg Barton, menjelaskan beberapa prinsip gagasan prinsip Islam liberal adalah sebagai berikut:

1. Pentingnya kontekstual ijtihad.

2. Komitmen terhadap rasionalitas dan pembaharuan.

${ }^{18}$ Adian Husaini, Islam Liberal, Pluralisme Agama dan Diabolisme Intelektual, (Surabaya: Risalah Gusti, 2005), h. 33-38. 
3. Penerimaan terhadap pluralisme sosial dan pluralisme agama.

4. Pemisahan agama dari partai politik dan adanya posisi nonsektarian agama. ${ }^{19}$

Koordinator Islam liberal Ulil Absar Abdalla menuangkan gagasan-gagasan liberalnya tanpa tedeng aling-aling dengan mengatakan bahwa:

"Islam liberal bisa menerima bentuk negara sekuler...sebab, negara sekuler bisa menampung energi kesalehan dan energi kemaksiatan sekaligus". ${ }^{20}$

Aktivis Islam liberal lainnya, Denny JA, juga menulis gagasan liberal sebagai berikut:

"Sudah saatnya komunitas Islam Liberal di Indonesia mengembangkan sebuah teologi tersendiri yang sah secara substansi dan metodologi, yaitu teologi Islam Liberal. Ini sebuah filsafat keagamaan yang bersandar kepada teks dan tradisi Islam tersendiri, yang membenci pembenaran pada sebuah kultur liberal. Dalam politik, teologi itu menjadi Teologi Negara Sekuler (TNS), yaitu sebuah filsafat keagamaan, yang menggali dari teks dan tradisi Islam, yang paralel atau membenarkan perlunya sebuah negara yang sekuler sekaligus demokratis." 21

Dawam Raharjo, seorang tokoh Muhammadiyah Indonesia, memberi pembelaan keberadaan Ahmadiyah di Indonesia dengan statemen yang agak radikal, sebagai berikut:

"Ahmadiyah sama dengan kita... Jadi kita tidak bisa menyalahkan atau membantah akidah mereka, apapun akidah mereka itu. Kita menyangka, akidah mereka menyimpang. Misalnya, mereka percaya kalau Mirza Ghulam Ahmad adalah Nabi. Tapi kalau sudah menjadi kepercayaan mereka mau apa? Itu kan soal kepercayaan. Itu kan sama saja dengan kita percaya kepada Nabi Muhammad saw."22

Said Aqiel Siradj, ketua Syuriah Pengurus Besar NU, juga mengapresiasikan pikiran-pikirannya yang radikal megatakan:

${ }^{19}$ Greg Barton, Gagasan Islam Liberal di Indonesia, (Jakarta: Paramadina, 1999), 23.

${ }^{20}$ Majalah Tempo, edisi 19-25 Nopember 2001.

${ }^{21}$ Adian Husaini, Islam Liberal...., h. 39.

${ }^{22}$ Majalah Gatra, edisi 21 Desember 2002. Lihat Pula www.Islamlib.com 
"Agama yang membawa misi Tauhid adalah Yahudi, Nasrani (Kristen) dan Islam. Ketiga agama tersebut datang dari Tuhan melalui Rasul dan Nabi pilihan. Agama Yahudi diturunkan melalui Musa, Nasrani diturunkan melalui Isa (Yesus), dan Islam melalui Muhammad. Kedekatan ketiga agama Samawi yang sampai saat ini masih dianut oleh umat manusia itu semakin tampak jika dilihat dari geneologi ketiga utusan (Musa, Isa dan Muhammad) yang bertemu pada Ibrahim sebagai the foundation father's bagi agama tauhid. Singkatnya, ketiga agama tersebut sama-sama memiliki komitmen untuk menegakkan kalimat tauhid... Dari ketiga macam Tauhid di atas, Tauhid Kanisah Ortodoks Syiria tidak memiliki perbedaan yang berarti dengan Islam." 23

Cendikiawan Muslim, Alwi Shihab memberi argumen yang logis dan politis dengan mengatakan bahwa:

"Prinsip lain yang digariskan oleh al-Qur'an adalah pengakuan eksistensi orang-orang yang berbuat baik dalam setiap komunitas beragama dan dengan begitu, layak memperoleh pahala dari Tuhan. Lagi-lagi, prinsip ini memperkokoh ide mengenai pluralisme keagamaan dan menolak eksklusivisme keagamaan tidak sesuai dengan semangat al-Qur'an. Sebab al-Qur'an tidak membedabedakan antara satu komunitas agama dari lainnya." ${ }^{24}$

Pada sisi lain Abdul Munir Mulkhan, memberi gagasangagasan liberal dalam mengubah nuansa berfikir yang lebih praksis sebagai berikut:

"Jika semua agama memang benar sendiri, penting diyakini bahwa surga Tuhan yang satu itu sendiri terdiri banyak pintu dan kamar. Tiap pintu adalah jalan pemeluk tiap agama memasuki kamar surganya. Syarat memasuki surga ialah keikhlasan pembebasan manusia dari kelaparan, penderitaan, kekerasan dan ketakutan tanpa melihat agamanya. Inilah jalan universal surga bagi semua agama. Dari sini kerja sama dan dialog pemeluk berbeda agama jadi mungkin." ${ }^{25}$

Sementara itu, Abdurrahman Wahid, saat menjabat sebagai

${ }^{23}$ Adian Husaini, Islam Liberal....., h. 41.

${ }^{24}$ Alwi Shihab, Islam Inklisif: Menuju Sikap Terbuka dalam Agama, (Bandung: Mizan, 1997), h.108-109.

${ }^{25}$ Abdul Munir Mulkhan, Ajaran dan Jalan Kematian Syekh Siti Jenar, (Yogyakarta: Kreasi Wacana, 2002), h. 44. 
Presiden Indonesia pernah berpidato pada malam perayaan Natal bersama, 27 Desember 1999. Beliau menyampaikan pesannya bahwa:

"Bagi saya, peringatan Natal adalah peringatan kaum Muslim juga. Kalau kita konsekuen sebagai seorang Muslim merayakan kelahiran Nabi Muhammad saw, maka adalah harus konsekuen merayakan malam Natal." ${ }^{26}$

Tokoh gerakan sekularisasi di Indonesia, Nurcholish Madjid, juga tidak hanya berpendapat dalam bidang sosial politik, tetapi juga mempromosikan Teologi inklusif. Pendapatnya ditulis oleh Sukidi dalam sebuah buku yang berjudul "Teologi Inklusif Cak Nur". Dalam buku tersebut diuraikan:

"Bangunan epistimologi teologi inklusif Cak Nur diawali dengan tafsiran al-Islam sebagai sikap pasrah ke hadirat Tuhan. Kepasrahan ini, kata Cak Nur menjadi karakteristik pokok semua agama yang benar. Inilah kata yang tersingkap dalam al-Qur'an, bahwa semua agama yang benar adalah Islam, yakni sikap berserah diri ke hadirat Tuhan (Q.S.29: 46). Dalam konteks inilah, sikap pasrah menjadi kualifikasi signifikan pemikiran teologi inklusif Cak Nur. Bukan saja kualifikasi seorang beragama Islam, tetapi 'muslim' itu sendiri (secara generik) juga dapat menjadi kualifikasi bagi penganut agama lain, khususnya para penganut kitab suci, baik Yahudi maupun Kristen. Maka konsekwensi secara teologis bahwa siapa pun di antara kita, baik sebagai seorang Islam, Yahudi, Kristen maupun Shabi'in yang benar-benar beriman kepada Tuhan dan hari kemudian, serta berbuat kebaikan, maka akan mendapatkan pahala di sisi Allah...(Q.s.2:62, 5:69). Dengan kata lain, sesuai firman Tuhan ini, terdapat jaminan teologis bagi umat beragama, apa pun 'agama'nya, untuk menerima pahala (surga) dari Tuhan." ${ }^{27}$

Di lain sisi tokoh pemikir liberal Ahmad wahib mengekplorasikan fikiran-fikiranya dengan mengatakan bahwa:

"Wah, andaikata hanya tangan kiri Muhammad memegang kitab, yaitu al-Hadis, sedang dalam tangan kanannya tidak ada Wahyu Allah (al-Qur'an), maka dengan tegas aku akan

${ }^{26}$ Adian Husaini, Gus Dur Mau Kemana; Telaah Kritis Atas Pemikiran dan Politik Keagamaan Presiden Abdurrahman Wahid, (Jakarta: DEA Press, 2002), h. 167.

${ }^{27}$ Sukidi, Teologi Inklusif Cak Nur, Kompas, 2001, Dalam Husaini Adian Islam Liberal, h. 44. 
berkata bahwa Karl Marx dan Frederich Engels lebih hebat dari utusan Tuhan itu. Otak kedua orang itu yang luar biasa dan pengabdiannya yang luar biasa pula, akan meyakinkan setiap orang bahwa kedua orang besar itu adalah penghuni surga tingkat pertama, berkumpul dengan para Nabi dan Syuhada." ${ }^{28}$

Nurcholish Majid, yang tak henti-hentinya memberi argumen dengan ikhlas guna mengangkat langit keilmuan di kalangan intelektual dengan begitu dapat mengartikulasi nilai pemikiran keagamaan yang lebih netral, inovatif dan produktif, seperti di bawah ini:

"Semua agama, dalam inti yang paling mendalam adalah sama, dalam bulan yang suci ini karena bersama ada perayaan Waisak, Maulid Nabi Muhammad saw, dan kenaikan Isa alMasih, kita semua harus menuju pada kedamaian." ${ }^{29}$

Taufik Adnan Amal salah seorang sosok pemikir cendikiawan muda yang kritis dari UIN Makasar memberi gagasan-gagasan liberalnya sebagai berikut:

"Uraian dalam paragraf-paragraf berikut mencoba mengungkapkan secara ringkas proses pemantapan teks dan bacaan al-Qur'an sembari menegaskan bahwa proses tersebut masih meninggalkan sejumlah masalah mendasar, baik dalam otografi teks maupun pemilihan bacaannya, yang kita warisi dalam mushap tercetak dewasa ini. Karena itu, tulisan ini juga menggagas bagaimana menyelesaikan itu lewat suatu upaya penyuntingan edisi kritis al-Qur'an"30.

Sumanto al-Qurtuby, pada Jurnal Justisia, edisi 27/2005 yang di kutip oleh Adian Husaini memberikan ide-idenya yang liberal dan dinamis sebagai berikut:

"Dengan demikian, wahyu sebetulnya ada dua: "wahyu verbal" ("wahyu eksplisit" dalam bentuk redaksional bikinan Muhammad) dan "wahyu non verbal" ("wahyu implisit" berupa konteks sosial waktu itu)". ${ }^{31}$

${ }^{28}$ Ahmad Wahib, Pergolakan Pemikiran Islam, (Jakarta: LP3ES, 2003), h. 98.

${ }^{29}$ Pidato dalam acara peringatan Waisak Nasional di JCC, 15 Mei 2003, dalam Adian Husaini, Apa Kata 'Orang-Orang IAIN/UIN' Seputar Islam, Pada kegiatan Internasional Workshop on Islamic Higher Learning Indonesia. Desember 20-23 2005 Di Wisma Sahida.

${ }^{30}$ Makalah "Edisi Kritis al-Qur'an" dalam Adian Husaini, Ibid.

${ }^{31}$ Ibid. 
Dari tokoh-tokoh berfikir di atas, yang telah mengeksplorasikan gagasan-gagasannya merupakan kesadaran kolektif dan konstruktif dalam membangun horizon berfikir yang tercerahkan dengan mengangkat langit keilmuan yang lebih dinamis dan praksis. Hal tersebut disesuaikan dengan suasana kultur dan struktural pemahaman keagamaan yang lebih kompetitif dan itu suatu keharusan sebagai anak bangsa yang memiliki kesadaran moral berfikir dalam membangun tata nilai beragama. Dengan demikian revitalisasi dan realisasi kehidupan keberagamaan tidak kehilangan konteks dan makna empiriknya. Keharusan tersebut dapat dimaknai sebagai jawaban masyarakat beragama terhadap perubahanperubahan yang terjadi yang dirasakan oleh umat manusia secara cepat (massif).

Jaringan Islam Liberal memberi semangat berfikir dalam mengartikulasi nilai-nilai keagamaan yang yang lebih holistik dan universal dengan mengedepankan sikap ilmiah dan argumentatif. Menurut JIL satu-satunya menuju kemajuan Islam adalah dengan mempersoalkan cara kita menafsirkan agama. Untuk menuju ke arah itu memerlukan beberapa hal sebagaimana yang dikemukakan oleh Ulil Abshar Abdalla, yaitu:

1. Penafsiran Islam yang non-literal, subtansial, kontekstual dan sesuai dengan denyut nadi peradaban manusia yang sedang dan terus berubah.

2. Penafsiran Islam yang dapat memisahkan mana unsur-unsur yang di dalamnya merupakan kreasi budaya setempat, dan mana yang merupakan nilai fundamental. Kita harus membedakan mana ajaran dalam Islam yang merupakan pengaruh kultur Arab dan mana yang tidak. Islam itu kontekstual dalam makna bahwa nilai-nilainya yang universal harus diterjemahkan dalam konteks tertentu, misalnya konteks Arab, Melayu, Asia Tengah dan seterusnya. Tetapi bentuk-bentuk Islam yang kontekstual itu hanya ekspresi budaya dan tidak diwajibkan mengikutinya. Aspek-aspek Islam yang merupakan cerminan kebudayaan Arab misalnya, soal jilbab, potong tangan, qishash, rajam, jenggot, jubah tidak wajib diikuti, karena itu hanya ekspresi lokal partikular Islam di Arab. Yang harus diikuti adalah nilai-nilai universal yang melandasi praktek-praktek itu. Jilbab intinya adalah mengenakan pakaian 
yang memenuhi standar kepantasan umum (publik decency). Kepantasan umum tentu sifatnya fleksibel dan berkembang sesuai perkembangan kebudayaan manusia.

3. Umat Islam hendaknya tidak memandang dirinya sebagai "masyarakat" atau "umat" yang terpisah dari golongan yang lain. Umat manusia adalah keluarga universal yang dipersatukan dengan kemanusiaan itu sendiri. Kemanusiaan adalah nilai yang sejalan, bukan berlawanan dengan Islam. Larangan kawin beda agama, dalam hal ini antara perempuan Islam dengan lelaki non Islam menrutnya, sudah tidak relevan lagi. al-Qur'an sendiri tidak pernah dengan tegas melarang itu, karena al-Qur'an menganut pandangan universal tentang martabat manusia yang sederajat, tanpa melihat perbedaan agama. Segala produk hukum Islam klasik yang membedakan antara kedudukan orang Islam dan non Islam harus diamandemen berdasarkan prinsip kesederajatan universal dalam tataran kemanusiaan.

4. Kita membutuhkan struktur sosialyang dengan jelas memisahkan mana kekuasaan politik dan mana kekuasaan agama. Agama adalah urusan pribadi; sementara pengaturan kehidupan publik adalah sepenuhnya hasil kesepakatan masyarakat malalui prosedur demokrasi. Nilai-nilai universal agama tentu diharapkan ikut membentuk nilai-nilai publik, tetapi doktrin dan praktek peribadatan agama yang sifatnya partikular adalah urusan masinmasing agama. ${ }^{32}$

Dari informasi tersebut di atas, dapat membuka pemaham kita bahwa seharusnya kita bisa membawa pemikiran kita yang proporsional mana Islam Universal dan mana yang partikular, dengan demikian manusia dapat memahami, membedakan dan mengelaborasi gagasan keberagamaan yang semakin dinamis.

Di lain sisi Ulil Abshar Abdalla meletakkan kedudukan Rasul Muhammad saw. dalam konteks pemikiran bahwa, Muhammad adalah tokoh historis yang harus dikaji dengan kritis, (sehingga tidak hanya menjadi mitos yang dikagumi saja, tanpa memandang aspek-aspek beliau sebagai manusia yang juga ada kekurangannya) sekalipun panutan yang harus diikuti. ${ }^{33}$

\footnotetext{
${ }^{32}$ Internet, www/islamlib.yahoo.com

${ }^{33}$ Ulil Abshar Abdalla dkk., Islam Liberal dan Fundamental, Sebuah Pertarungan
} 
Dalam konteks sosial politik di Madinah, Rasul tentu menghadapi banyak keterbatasan. Rasul memang berhasil menerjemahkan cita-cita sosial universal dan spiritual partikular Islam di madinah, tetapi Islam sebagaimana yang diwujudkan di sana adalah Islam historis, partikular dan kontekstual. ${ }^{34}$

Umat Islam harus berijtihad mencari formula baru dalam menerjemahkan nilai-nilai itu dalam konteks kehidupan mereka sendiri. Islamnya di madinah adalah satu kemungkinan menerjemahkan Islam yang universal di muka bumi; ada kemungkinan lain untuk menerjemahkan Islam dengan cara lain, dalam konteks yang lain pula. Islam di Madinah adalah salah satu diantaranya, keadaan Islam yang hadir di muka bumi. Oleh karena itu, umat Islam tidak sebaiknya mandek dengan melihat contoh di Madinah saja, sebab kehidupan manusia terus bergerak menuju perbaikan dan penyempurnaan. Baginya, wahyu tidak berhenti pada zaman Nabi, wahyu terus bekerja dan turun kepada manusia. Wahyu verbal memang telah selesai dalam al-Qur'an, tetapi wahyu non verbal dalam bentuk ijtihad akal manusia terus berlangsung.

Temuan-temuan besar dalam sejarah manusia sebagai bagian dari usaha perbaikan mutu kehidupan adalah wahyu Tuhan pula, karena temuan-temuan itu dilahirkan oleh akal manusia yang merupakan anugerah Tuhan. Karena itu, seluruh karya cipta manusia, tidak peduli agamanya adalah milik orang Islam juga; tidak ada gunanya orang Islam membuat tembok ketat antara peradaban Islam dan peradaban Barat, yang satu dianggap unggul, yang lain dianggap rendah. Sebab setiap peradaban adalah hasil karya manusia, dan karena itu milik semua bangsa, termasuk milik orang Islam.

Jaringan Islam Liberal dewasa ini telah berproses dan telah banyak kiprahnya yang dilakukan, setidaknya mensosialisasikan wacana keislaman yang memang bisa dibilang berani, terbuka dan demokratis. Membuka perdebatan dengan siapa saja, dan yang paling penting adalah mencoba menawarkan model keislaman yang humanis, inklusif dan dinamis.

Wacana, (Yogyakarta: Elsaq Press, 2003), h.3.

34 Yusuf Qardhawi, Islam Radikal Dan Upaya Pemecahannya, terj., (Solo: Intermedia, 2004). 


\section{E. Penutup}

Setelah diuraikan secara singkat, JIL dengan pemikiranpemikirannya, mencoba menyatukan komunitas Islam dalam bingkai modernitas. Salah satu pemikiran JIL yang perlu diapresiasi adalah konsep tentang pluralisme, modernisasi, demokrasi dan sejenisnya, yang sampai saat ini bagi sebagian umat Islam masih dianggap sebagai bukan ajaran orisinal Islam. Bagi JIL konsep tersebut memiliki pijakan teologis yang kuat dalam al-Qur'an bahkan Sunnah Rasul dan generasi-generasi awal Islam. Bila tidak, maka fenomena yang akan berkembang merebaknya kekerasan yang dalam kasus-kasus tertentu sarat dengan muatan agama, atau minimal dilakukan oleh umat beragama, terutama umat Islam.

Maraknya tindakan kekerasan ini, selain muncul akibat ketidak mampuan manusia dalam menyikapi modernitas yang sangat kompleks, juga berpeluang pada pola keberagamaan mereka yang mengedepankan eksklusivisme dan klaim kebenaran sepihak, serta tidak bisa membedakan Islam normatif dengan Islam sejarah. Dalam suasana ini, umat Islam melakukan mistifikasi Jihad, ${ }^{35}$ dan simbol agama yang lain, mereduksi sekedar memeperkental identitas diri dan menjadikannya sebagai media untuk menyerang kelompok dan umat lain yang berbeda.

Dengan konteks itu JIL, mencoba membangun dan mengembangkan suasana beragama yang transformatif dan inklusif, menampakkan signifikansinya untuk selalu "dilirik" oleh komunitas umat. Melalui pemahaman keagamaan yang holistik dan pola keagamaan yang inklusif, umat Islam diharapkan dapat menyelesaikan krisis kemanusiaan, serta menjadikan modernitas sebagai proses yang memberikan manfaat sebesar-besarnya bagi manusia.

\section{Daftar Pustaka}

Abdalla, Ulil Abshar, dkk., Islam Liberal dan Fundamenta, Sebuah Pertaungan Wacana, Jogjakarta: Elsaq Press, 2003.

${ }^{35}$ Oliver Roy, Gagalnya Islam Politik, (Jakarta: PT. Serambi Ilmu Semesta, 1996), h. 83-87. 
Abdillah, Maskuri, Islam dan Politik Orde Baru, Yogyakarta: Tiara Wacana, 1998.

Aly, Fachri dan Effendy, Bahtiar, Merambah jalan Baru Islam, Bandung: Mizan, 1987.

Al-Anshori, Fauzan, Melawan Konspirasi Jaringan Islam Liberal, Yogyakarta: Pustaka al-Furqan, 2003.

Azra, Azyumardi, Konflik Baru Antara Peradaban, Globalisasi, Radikalisme dan Pluralitas, Jakarta: Rajawali Press, 2002.

Barton, Greg, Gagasan Islam Liberal di Indonesia, Jakarta: Paramadina, 1999.

Binder, Leonard, Islamic Liberalism A Critique of Depvelopment Ideologis, Cichago \& London: Cicago Press,1988.

Husaini, Adian dan Hidayat, Nuim, Islam Liberal, Sejarah, Konsepsi, Penyimpangan dan Jawabannya, Jakarta: Gema Insani Pres, 2002.

, Gus Dur Mau Kemana; Telaah Kritis Atas Pemikiran dan Politik Keagamaan Presiden Abdurrahman Wahid, Jakarta: DEA Press, 2002.

_- Islam Liberal, Pluralisme Agama dan Diabolisme Intelektual, Surabaya: Risalah Gusti, 2005.

__, Apa Kata 'Orang-Orang IAIN/UIN’ Seputar Islam, Pada kegiatan Internasional Workshop on Islamic Higher Learning Indonesia. Desember 20-23 2005 Di Wisma Sahida.

Internet, Www/islamlib.yahoo.com.

Jaiz, Hartono Ahmad, Menangkal Bahaya JIL dan FLA, Jakarta: Pustaka Al-Kautsar, 2005.

_- Teologi Baru Politik Islam, Pertautan Agama, Negara dan Demokrasi, Yogyakarta: Galang Press, 2001.

_- Masyarakat Agama dan Pluralisme Keagamaan, Perbincangan mengenai Islam, Masyarakat Madani dan Etos Kewirausahaan, Yogyakarta: Galang Press, 2001.

__, Islam dan Negara, Jakarta: Paramadina, 1998.

Karim, M. Rusly, Cendikiawan Muslim Indonesia dan Politik Orde Baru, Yogyakarta: Tiara Wacana, 1998. 
Kurzaman, Charles (Edt), Wacana Islam Liberal, pemikiran Islam Kontemporer Tentang Isus-Isu Global, Jakarta: Paramadina, 2003

Ma'arif, Ahmad Syafi'i, Islam dan Masalah Kenegaraan, Jakarta: LP3S, 1985.

_- Peta Bumi Pemikiran Islam di Indonesia, Bandung: Mizan, 1992.

Madjid, Nurcholish, Islam Kemodernan Dan Keindonesiaan, Bandung: Mizan, 1989.

Majalah Gatra, edisi 21 Desember 2002.

Majalah Tempo, edisi 19-25 Nopember 2001.

Mulkhan, Abdul Munir, Ajaran dan Jalan Kematian Syekh Siti Jenar, Yogyakarta: Kreasi Wacana, 2002.

Qadir, Juli, "Wajah Islam Liberal di Indonesia: Sebuah Penjajagan Awala” dalam Al Jami’ah VOL.40, no. 2 July Desember 2002.

Qarḍawi, Yusuf, Islam dan Globalisasi Dunia, (Terj), Jakarta: Pustaka al-Kautsar, 2001.

__, Islam Radikal: Analisis Terhadap Radikalisme dalam Berislam dan Upaya Pemecahannya, (Terj.), Solo: IKAPI, 1996.

Raharjo, M. Dawam, Intelektual, Intelegensia dan Prilaku Politik Bangsa, Bandung: Mizan, 1992.

Rahman, Fazlur, Islam, Chicago dan London, Unv. Of Chicago Press, 1973.

Roy, Oliver, Gagalnya Islam Politik, (Terj.), Jakarta: PT. Serambi Ilmu Semesta, 1996.

Shihab, Alwi, Islam Inklisif: Menuju Sikap Terbuka dalam Agama, Bandung: Mizan, 1997.

Sukidi, Teologi Inklusif Cak Nur, Kompas, 2001.

Thalib, M. dan Fajar, Haris, Dialog Bung Karno - A. Hassan, Yogyakarta: Sumber Ilmu,1985.

Wahib, Ahmad, Pergolakan Pemikiran Islam, Jakarta: LP3ES, 2003.

Winarno, Budi, Globalisasi Wujud Imperialisme Baru, Yogyakarta:Tajidu Press, 2004. 